\author{
Agnieszka Wojtasiak-Terech \\ Wroclaw University of Economics and Business \\ e-mail: agnieszka.wojtasiak-terech@ue.wroc.pl \\ ORCID: 0000-0001-6389-7538
}

\title{
REGIONAL COMPETITIVENESS \\ AND LOCAL GOVERNMENT DEBT
}

\begin{tabular}{l}
\hline KONKURENCYJNOŚĆ REGIONU A ZADLUŻENIE \\
JEDNOSTEK SAMORZĄDU TERYTORIALNEGO
\end{tabular}

DOI: $10.15611 / \mathrm{pn} .2019 .12 .12$

JEL Classifiaction: H74, O18, R11, R58

Summary: The goal of the research was to select measures of regional competitiveness and analyze if in the considered period changes in value of these measures were in line with changes in the debt level of different forms of municipalities (communes). The survey was conducted for the Lower Silesia region and the municipalities located there. Data covered the period 2005-2015. The main measure of regional competitiveness selected by the author was regional GDP per capita. The additional measures were: labour productivity, employment rate, average monthly salary and business density. The survey indicated that the value of communes debt in Lower Silesia increased, even if in some years for particular forms of communes the level of debt was decreasing. At the same time generally an increase of competitiveness measures in the region was observed. In most of the analyzed years the direction of changes in municipalities debt was the same as that of changes of regional competitiveness measures.

Keywords: regional competitiveness, municipalities debt, competitiveness measures.

Streszczenie: Celem artykułu był wybór miar, za pomocą których można określić konkurencyjność regionu, oraz zbadanie, czy w analizowanym okresie zmiany wartości tych miar były zgodne ze zmianami zadłużenia gmin. Analiza została przeprowadzona dla województwa dolnośląskiego oraz zlokalizowanych na jego terenie gmin. Dane obejmowały lata 2005-2015. Jako główną miarę konkurencyjości regionu wybrano PKB na mieszkańca. Dodatkowo do analizy przyjęto następujące miary: produktywność, wskaźnik zatrudnienia, średnie wynagrodzenie i liczbę zarejestrowanych przedsiębiorstw. Badanie wykazało, iż w analizowanym okresie nastąpił wzrost zadłużenia wszystkich typów gmin. W tym czasie zaobserwowano również wzrost wartości analizowanych miar konkurencyjności regionu (w niektórych latach wystąpiły pojedyncze przypadki spadku określonych miar). W większości badanych lat zmiany długu gmin miały ten sam kierunek co zmiany wartości miar konkurencyjności regionu.

Słowa kluczowe: konkurencyjność regionu, zadłużenie gmin, miary konkurencyjności. 


\section{Introduction}

Financing plays an important role in economic development. In order to finance assigned tasks and reach their goals local governments use own financial resources or borrow money from banks, government or the capital market. Over the past few years several local governments in Poland have resorted to debt financing in order to cover the budget deficit, repay old debts or finance infrastructure projects. Municipalities' debt has the form of bonds and loans, with money borrowed from banks, the capital market and government.

The high level of local government debt is one of the ongoing concerns of local authorities in Poland. At the same time the key element of policy makers is to ensure high competitiveness of the region, which means improving the standard of living, the well-being of people and firms and achieving a socio-economic and territorial cohesion (Borozan, 2008). Taking into the account the fact that debt financing cannot be used to cover current expenditure of municipalities in Poland, it should be allocated for capital investment and contribute to the regional development and competitiveness of the region.

There are several studies on regional competitiveness, its drivers and measures. Researchers and practitioners have conducted a broad analysis of local government debt. The literature also presents theories on the relationship between debt and economic growth on a national level, but there are only a few publications on this topic on a regional and local level. The area of analyzing the relation between regional competitiveness and local debt needs exploration, and the results can be important particularly for local policy makers and creditors. This study is a preliminary step for filling the gap and conducting a broader analysis of this relation.

The goal of the research is to select aggregate measures of regional competitiveness and analyze if changes in the value of these measures are in line with changes in the debt level of different forms of municipalities. The survey was conducted for the Lower Silesia region and the municipalities located there. Data covered the period 2005-2015. The main measure of regional competitiveness selected by the author is regional GDP per capita. The additional measures are: labour productivity, employment rate, average monthly salary and business density.

In the first section the concept of regional competitiveness and approaches to measure it are presented. Since as the main measure of competitiveness regional GDP per capita is selected, the author provides insight into some theories and empirical studies concerning public debt and economic growth. The second part includes information about the scope of the study. The next section shows results of the research, and The final section includes conclusions and lists important factors which could influence the findings. 


\section{Literature overview}

\subsection{Definition of regional competitiveness}

There is no single, all-encompassing theory that provides a generally accepted definition and explanation of regional competitiveness (Martin, 2005). Much of the literature on regional competitiveness is rooted within traditional and modern theories on competitiveness. Moreover, the notion of competitiveness has been considered at micro (firm), macro and meso level (Łaźniewska, Chmielewski, and Nowak 2012).

Of the many theories and concepts that exist at micro-level, some clear relevance for a better understanding of regional competitiveness comes from urban growth theory, 'new' institutional economics, business strategy economics and Schumpeterian/evolutionary economics. At the company level there exists a reasonably clear and straightforward understanding of the notion of competitiveness based on the capacity of firms to compete, to grow, and to be profitable (Martin, Cambridge Econometrics, and Ecorys-Nei, 2003). The macro perspective is related to a nation's and macro-region's competitiveness and the concept of competitiveness is much more poorly defined and more strongly contested. From this perspective the notion of 'competitiveness' was influenced to a wide extent by: classical theory, neoclassical theory, Keynesian economic theory, development economics, new economic growth theory and new trade theory. In addition to the macro and micro perspectives, the understanding of regional competitiveness also requires insights in sociology and economic geography. The label 'meso-level' is used to indicate the intermediate level between the individual and the aggregate macro-level, which covers the industrial district and the local area (i.e. the region) (Cellini and Soci, 2002). The notion of regional competitiveness is neither a macro-economic (national) nor micro-economic (firm-based) one as a region is neither a simple aggregation of firms nor a scaled version of nations (Gardiner, Martin, and Tyler, 2012; Budd and Hirmis, 2004). An extensive literature review of the theories related to the concept of territorial competitiveness can be found in the surveys by Martin et al. (2003), Siudek and Zawojska (2014), Szafranek (2010), Huggies, Izushi, and Thompson (2013), Martin (2005).

Taking into the account the different theories which influenced the notion of 'regional competitiveness' there are plenty of definitions trying to explain its meaning, but only some, most important for the problem considered in the article will be presented. Storper (2008) defines regional competitiveness as the capability of a region to attract and maintain firms with stable or raising market shares in an activity, while maintaining stable or increasing standards of living for those who participate in it. A similar approach was presented by Szlachta (1996) and Pietrzyk (2000). Annoni, Dijkstra, and Gargano (2017) add to the definition the dimension of sustainability. Regional competitiveness is defined as the ability to offer an attractive 
and sustainable environment for firms and residents to live and work in. 'Sustainable' in this definition is not used in the purely ecological-environmental sense, but rather in the sense of a region's capacity to provide an attractive environment in both the short and long term. Some approaches to define regional competitiveness underline that it is related to the ability to adapt to changes in the environment (Ponikowski, 2004; Winiarski, 1999; Martin, 2005) or to constantly develop (Strahl, 2004). A comprehensive definition of regional competitiveness which takes into account the drivers of competitiveness and its outputs, is suggested by Parkinson et al. (2006). They defined it as the ability of a region to continually upgrade their business environment, skill base, and physical, social and cultural infrastructures, to attract and retain high-growth, innovative and profitable firms, and an educated, creative and entrepreneurial workforce, to thereby enable it to achieve a high rate of productivity, high employment rate, high wages, high GVA per capita, and low levels of income inequality and social exclusion. For the purposes of this paper, this definition of competitiveness will be chosen as it comprises the most important aspect of regional competitiveness and indicates some measures of competitiveness.

\subsection{Approaches for regional competitiveness measurement}

There are two distinguishable approaches for analyzing and measuring regional competitiveness (Martin et al., 2003):

1) studies that analyze it as a cumulative outcome of factors, presented as competitiveness indices,

2) studies that focus on particular drivers of competitiveness and identify aggregate measures.

The development of regional competitiveness indices stems from the initial establishment of composite indices for the comparison of national competitiveness, such as the Global Competitiveness Index included in the Global Competitiveness Report published by the World Economic Forum and the World Competitiveness Ranking provided by the Institute for Management Development World Competitiveness Center. These indices combine a number of variables to produce a single composite competitiveness measure (Huggins et al., 2013). On regional level one can distinguish: the EU Regional Competitiveness Index created by DG for the Regional and Urban Policy (Annoni et al., 2017), the UK Competitiveness Index developed by Robert Huggins at Cardiff University (2003), the Regional Innovation Scoreboard prepared for the Directorate-General for the Internal Market, Industry, Entrepreneurship and SMEs, and the Atlas of Regional Competitiveness published by Eurochambers. A detailed overview of some of the regional competitiveness indices (almost 50 indices) is included in the Berger (2011) survey.

The commonly used models that have explored both the specific drivers of competitiveness and aggregate measures of regional competitiveness are "The Pyramid model" of Regional Competitiveness, and the Regional Competitiveness 
"Hat". A significant contribution to the literature on regional competitiveness factors and measures was provided by Porter's research.

"The Pyramid model" of Regional Competitiveness is composed of several different levels. The most aggregate measure of regional competitive advantage concerns the region's standard of living, conventionally captured by GDP or GVA per capita. Underpinning aggregate performance, measures of regional competitive advantage are revealed - namely productivity, the employment rate, wage levels and profit rates. These are in turn the outcome of the key 'drivers' of regional competitive performance - innovation, investment, human capital, economic structure, connectivity, quality of life and the structures of decision making. The model was initially created in 1997 by the European Commission (Łaźniewska et al. 2012), and then applied, upgraded and modified for the purposes of several surveys (Begg, 1999; Lengyel, 2004; Parkinson, Champion, Simmie, Turok, Crookston, Katz, and Park, 2006).

The Regional Competitiveness "Hat" is composed of regional outcomes, regional outputs, regional throughputs and determinants of regional competitiveness. In other words, the determinants of regional competitiveness (grouped by infrastructure and accessibility, human capital and productive environment) can be discovered by 'opening' the hat, layer by layer. A common indicator of regional competitiveness is GDP per head, which provides an, albeit incomplete, indicator of the average well-being of the population (Martin et al. 2003).

Porter's findings highlight the need for regional economic development policies to be particularly attuned to traded clusters, because these appear to drive local employment and local wages. Regions should focus on upgrading the productivity of all clusters in which they have a meaningful position, rather than attempting to migrate to more 'desirable' clusters. A region's ability to compete in its array of clusters with higher productivity has a decisive influence on the region's prosperity (Porter, 2003). A region's competitiveness is determined by the productivity with which it uses its human, capital, and natural resources.

Other theoretical and empirical studies on regional competitiveness measures which were important for the selection of aggregate competitiveness measures used in this research include studies conducted by Arnguren, Franco, Ketels, Murciego, Navarro, and Wilson (2010), Łaźniewska et al. (2012), Gardiner et al. (2012), Berger (2011), Martin (2005), Golejewska (2011), Szafranek (2010).

\subsection{Changes of public debt and economic growth}

As the main measure of regional competitiveness, the author selected GDP per capita, necessary to present some surveys on the relationship between this indicator and debt, however these studies are on a macro-level.

GDP is the most commonly used measure of economic growth. The relationship between debt and economic growth on a macro level has been the subject of several scientific papers and studies. In the literature dealing with this issue, empirical 
and theoretical discussions can be grouped into four main categories. In the first category there are analyses related to Keynesian economics, in which public debt has a positive influence on economic activity. Public debt influences the growth of domestic production which encourages private investors to increase investment. The second group can include neo-classical economists who present the opposite view. In their opinion public debt has a negative effect on growth. Modigliani (1961) and Saint-Paul (1992) take a theoretical approach based on a neoclassical growth model and suggest that an increase in public debt will always decrease the growth rate of the economy. This theory was confirmed by Kumar and Woo (2010) who used 38 advanced and emerging countries from 1970 to 2007 and find an inverse relationship between debt and growth (Alfonso and Jalles, 2013). The third category comprises proponents of the Ricardian theory, who state that public debt growth is neutral for economic growth (Misztal, 2011). The fourth category includes surveys which prove that the proper application of government debt can stimulate economic growth. However, if such debt continues to accumulate above the debt ceiling, there can be serious consequences for economic development. This category includes studies conducted for example by Reinhart and Rogoff (2010), Cecchetti, Mohanty, and Zampolli (2011). Their main result was that at moderate levels, debt can improve welfare and enhances growth, but high levels (measured by debt/GDP ratio) can be damaging. Additionally, Reinhart and Rogoff stated that the relationship between public debt and growth is remarkably similar across emerging markets and advanced economies. A different view was presented by Schclarek (2004), who concluded in his research that, for developing countries, there is always a negative and significant relation between debt and growth. For advanced countries, he does not find any strong evidence, suggesting that higher public debt levels are not necessarily associated with lower GDP growth rates. A critique of Reinhart and Rogoff's findings was undertaken by Herndon et al. (2014), proving that the relationship between public debt and GDP growth varies significantly by period and country. Their overall evidence refuted Reinhart and Rogoff's claim that public debt/GDP ratios above $90 \%$ consistently reduce a country's GDP growth.

\section{Scope of analysis and selected competitiveness measures}

\subsection{The Lower Silesia region in the territorial administrative system in Poland}

The territorial administrative system in Poland is based on three tiers where municipalities (communes) and counties perform the functions of local government, and voivodeships operate at the regional level. There are three forms of municipalities: urban commune (this type of local body covers the area of towns, some of them have county rights and operate as cities with county rights), rural commune (this type includes only the non-urban areas), and urban-rural commune (this type is a mixed or 
consolidated form covering towns or townships and the area of the villages adjacent to them). The Polish local government reforms adopted in 1998, which came into effect on 1 January 1999, created sixteen voivodeships.

The survey is conducted for the Lower Silesia region and communes located there. The Lower Silesia voivodeship is situated in south-west Poland and is one of the most urbanized regions in Poland. The majority of companies are linked to foreign capital. Electric machinery, high-tech motorisation, IT services and BPO sectors are highly developed sectors. The region comprises 169 communes (35 urban, 56 urban-rural and 78 rural).

Competitiveness measures and their changes were calculated for Lower Silesia. The debt level and its changes were calculated for all forms of communes. From the urban communes the author subtracted cities with county rights and analysed them separately. Data covered the period 2005-2015.

\subsection{Competitiveness measures selected for the analysis}

Taking into the account the approaches for measuring regional competitiveness included in the theoretical and empirical studies on regional competitiveness, in the presented survey as the measures of Lower Silesia voivodeship's competitiveness, the following were used:

1. Outcome indicator (the most aggregated measure) - regional GDP per capita.

2. Intermediate performance indicators for the region:

- labour productivity - regional GDP/employed persons,

- employment rate - employed persons/working population,

- average monthly salary,

- business density - number of registered entities per 10 thousand inhabitants.

\section{Regional competitiveness measures and municipal debt changes - results of research for Lower Silesia}

Figures 1, 2, 3 and 4 present yearly changes in debt for urban, rural, urban-rural communes and cities with county rights located in Lower Silesia and changes of selected competitiveness measures for the Lower Silesia region in the period 2005-2015.

The charts above illustrate that for all types of municipalities, debt was growing for most of the years in the considered period. The exceptions are the reductions of debt for urban communes in 2006-2007, 2012-2013, 2014-2015, rural communes in 2014-2015, urban-rural communes in 2011-2012, 2014-2015 and cities with county rights in 2005-2007. The highest and most significant debt growth took place between 2008 and 2011 (in the case of cities with county rights in 2007-2009). In the following years the debt growth was lower or in some cases it decreased. On average in the considered period the highest growth rate of debt was for cities with county rights and the lowest for urban communes. 


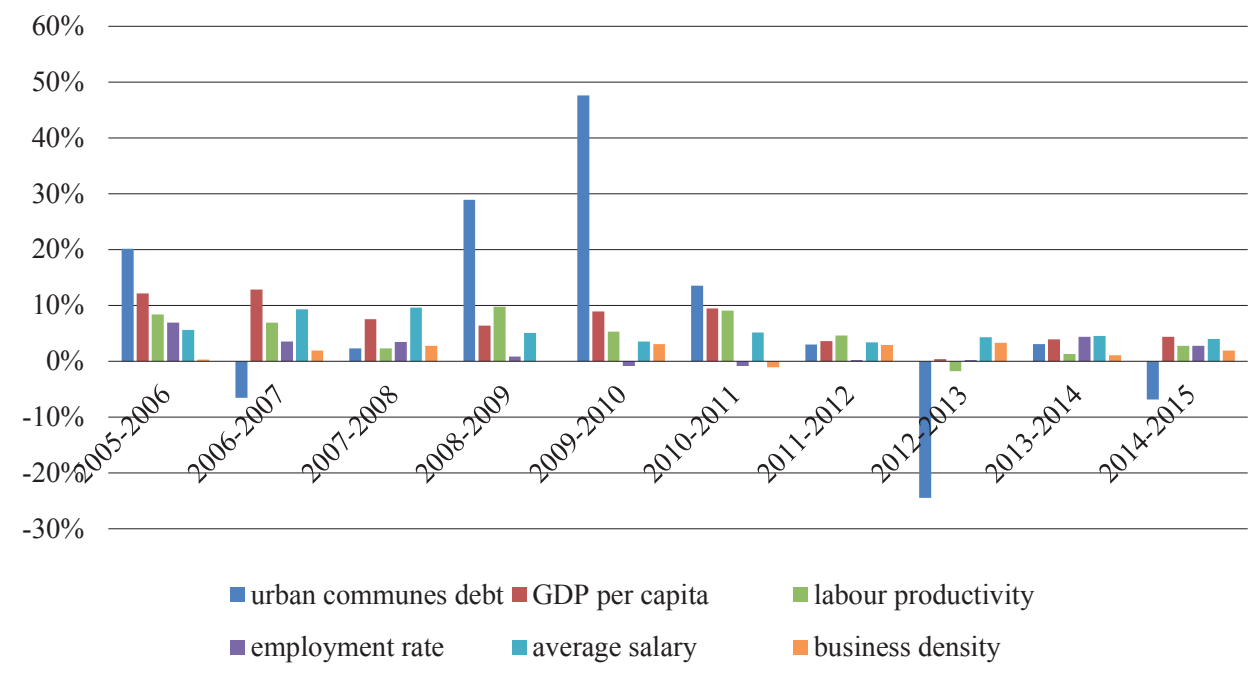

Fig. 1. Changes of debt and changes of competitiveness measures - urban communes Source: own study.

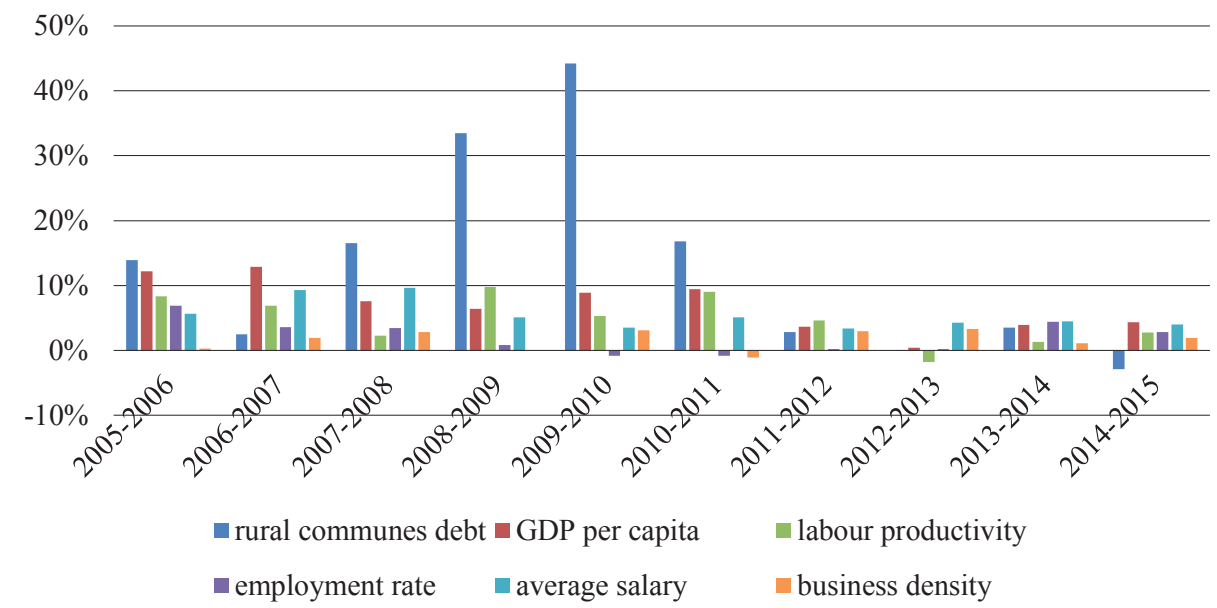

Fig. 2. Changes of debt and changes of competitiveness measures - rural communes Source: own study. 


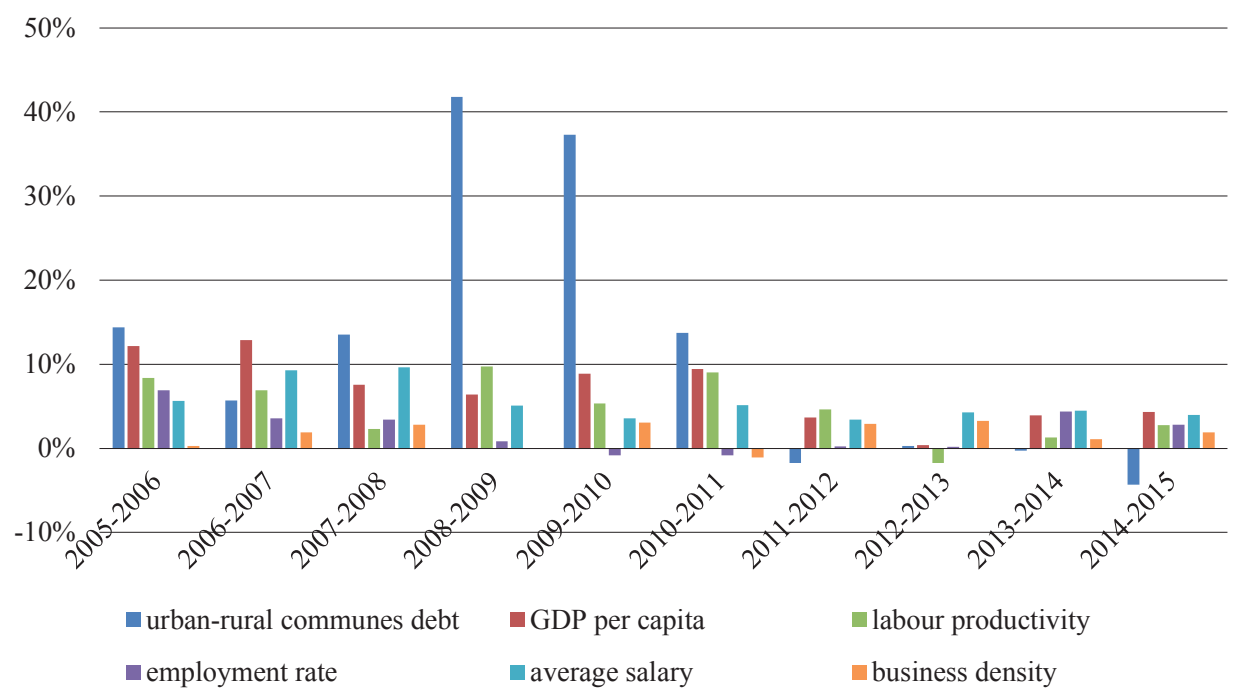

Fig. 3. Changes of debt and changes of competitiveness measures - urban-rural communes Source: own study.

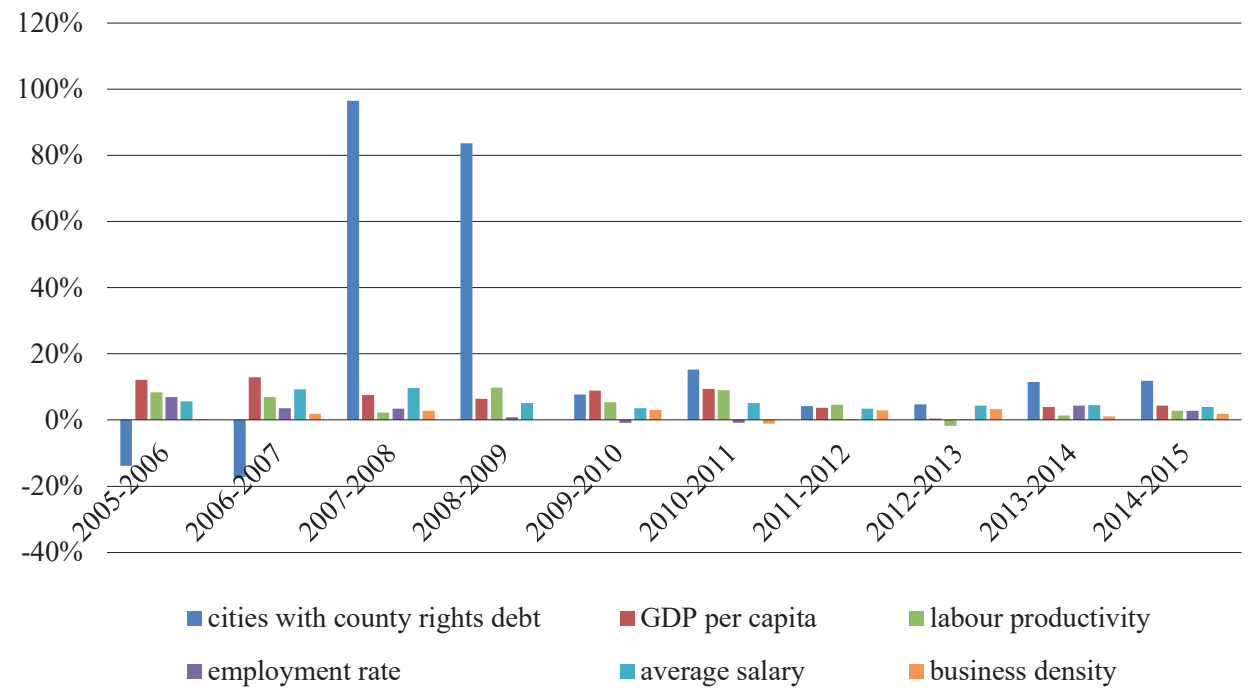

Fig. 4. Changes of debt and changes of competitiveness measures - cities with county rights communes Source: own study.

Between 2005 and 2015 one can observe a tendency of growth for almost all competitiveness measures in all types of municipalities. However, on average the 
debt growth for all forms of municipalities in 2005-2015 was higher than the growth of competitiveness measures in the Lower Silesia region (the average yearly growth rate of regional GDP per capita was 7\%, labour productivity $5 \%$, employment rate $2 \%$, average salary $5 \%$, and business density $1.2 \%$ ). Significant differences between debt growth and competitiveness growth are visible between 2007 and 2011.

There were several important factors which influenced changes in municipalities debt growth and competitiveness measures growth in the considered period. They include:

- obligation of co-financing EU grants - the co-financing requirement set by the Commission for each operational program represented a considerable fiscal burden for local governments. Every EU-funded project has to be co-financed, thus in the case of municipalities this means that they need to possess sufficient own resources to cover part of the project expenses. The "own sources" came from central budget grants, own local government budget and also local debt. Absorption of EU funds (particularly in 2008-2010) was positively related with the growth of capital investment expenditure, which had a positive impact on regional development. Municipalities had to fulfil the EU obligation related to communal infrastructure (for example water and savage system and waste management),

- advantages of joining the EU - using cohesion funds and structural funds in the considered period supported economic development and competitiveness of regions,

- facing economic crisis - local governments in Poland faced the effects of the economic crisis (lower budgetary revenues, higher deficits, necessity of limiting expenditures and capital investment), which influenced the growth of the deficit and the necessity of financing it,

- elections in 2010 - according to some theories, public authorities spend more on items visible to voters (and increase deficit and indebtedness) in the pre-election period and generally spend less after. The panel data study made in 2010 for Polish municipalities proved that in election years, capital spending and deficits were higher than in others (Kopańska, 2012),

- imposing additional tasks on local governments without ensuring equivalent financing, which added up to higher spend than that expected,

- changes in regulations - introducing new fiscal rules concerning purpose of borrowing, establishing in new Public Finance Law (2009) individual debt limit which conditions debt issuance on local government individual repayment capacity. The limit came into force in 2014, but for its calculation, data from 2011, 2012 and 2013 were taken, which forced local governments to change their budgetary policy a few years before 2014. The next change (in force from 2011) was associated with a ban on enacting the local budget, in which the planned current expenditures exceed expected the current revenues with the budget surplus from previous years and available resources, 
- status change of Walbrzych in 2012 from urban commune into city with county rights (this influenced particularly the changes in the level of debt in these two forms of municipalities).

\section{Conclusion}

The survey indicates that between 2005 and 2015 the value of communes' debt in Lower Silesia increased, even if in some years for particular types of communes the level of debt was decreasing. At the same time, one can observe the increase of GDP per capita, labour productivity, employment rate, average monthly salary and business density (only with some exceptions) in municipalities located there. However it must be underlined that in some periods debt growth rate was significantly higher than the growth of competitiveness measures. This situation was highly visible between 2007 and 2011.

In general it can be concluded that in most of the years of the considered period, municipalities' debt changes were moving in the same direction as the changes of selected regional competitiveness measures, yet it cannot be clearly stated that the growth of municipalities' debt in Lower Silesia influenced the growth of competitiveness measures, as there were several factors which determined the changes of all the analyzed variables.

This study constitutes preliminary research for a broader analysis of the relation between regional competitiveness and local debt.

\section{References}

Alfonso, A., and Jalles, T. (2013). Growth and productivity: The role of government debt. International Review of Economics and Finance, 25, 384-407.

Annoni, P., Dijkstra, L., and Gargano, N. (2017). The EU Regional Competitiveness Index 2016 (Working Paper WP 02/2017, European Commission). Retrieved from https://doi.org/10.2776/94425

Arnguren, M., Franco, S., Ketels, Ch., Murciego, A., Navarro, M., and Wilson, J. (2010). Benchmarking regional competitiveness in the European cluster observatory. Methodology Background Paper 1. European Commission. Retrieved from http://www.clusterobservatory.eu/eco/uploaded/ pdf/1288016756795.pdf

Begg, I. (1999). Cities and competitiveness. Urban Studies, 36(5-6), 795-809.

Berger, I. (2011). An overview and analysis on indices of regional competitiveness. Review of Economics and Finance, 1, 17-33.

Borozan, D. (2008). Regional competitiveness: Some conceptual issues and policy implications. Interdisciplinary Management Research, 4, 50-63.

Budd, L., and Hirmis, A. K. (2004). Competitiveness conceptual framework for regional competitiveness. Regional Studies, 39.8, 1015-1028. Retrieved from https://doi.org/10.1080/0034340042000292610 Cecchetti, S., Mohanty, S., and Zampolli, F. (2011). The real effects of debt (BIS Working Paper, no. 352). Basel: Bank for International Settlements.

Cellini, R., and Soci, A. (2002). Pop competitiveness. PSL Quarterly Review, 55(220), 71-101. 
Gardiner, B., Martin, R., and Tyler, P. (2012). Competitiveness, productivity and economic growth across the European regions. Regional Competitiveness, 55-78. Retrieved from https://doi.org/10.4324/ 9780203607046

Golejewska, A. (2011). Human capital and regional growth perspective. Barometr Regionalny, 11(1), 7-17.

Herndon, T., Ash, M., and Pollin, R. (2014). Does high public debt consistently stifle economic growth? A critique of Reinhart and Rogoff. Cambridge Journal of Economics, 38(2), 257-279.

Huggins, R., Izushi, H., and Thompson, P. (2013). Regional competitiveness: Theories and methodologies for empirical analysis. Journal of CENTRUM Cathedra (JCC): The Business and Economics Research Journal, 6(2), 155-172. Retrieved from https://doi.org/10.7835/jcc-berj-2013-0086

Kopańska, A. (2012). Local government debt policy in Poland between 1999 and 2010 with special focus on the first years of world economic crises. In L. Sedmihradska, N. Bobcheva, and M. Lados (Eds.), Local government finance in times of crisis: How to respond (pp. 114-131), Bratislava: NISPAcee Press.

Kumar, M., and Woo, J. (2010). Public debt and growth (IMF Working Paper WP 10/174).

Lengyel, I. (2004). The pyramid model: Enhancing regional competitiveness in Hungary. Acta Oeconomica, 54(3), 323-342.

Łaźniewska, E., Chmielewski, R., and Nowak, P. (2012). Definicje, modele i studia nad regionalną konkurencyjnością. In E. Łaźniewska, M. Gorynia (Eds.), Konkurencyjność regionalna. Koncepcje-strategie-przykłady (pp. 24-62). Warszawa: PWN.

Martin, R., Cambridge Econometrics, Ecorys-Nei. (2003). A Study on the Factors of Regional Competitiveness: Report for the European Commission DG Regio. Retrieved from https://ec.europa.eu/ regional_policy/sources/docgener/studies/pdf $/ 3 \mathrm{cr} / \mathrm{competitiveness.pdf}$

Martin, R. (2005). Thinking about regional competitiveness: Critical issues (Policy paper prepared for East Midland Development Agency). Nottingham Trent University. Retrieved from: http://irep. ntu.ac.uk/id/eprint/519/1/202832_thinkingaboutregionalcompetitiveness2005.pdf.

Misztal, P. (2011). Dług publiczny i wzrost gospodarczy w krajach członkowskich Unii Europejskiej. Zeszyty Naukowe SGGW w Warszawie, Polityki Europejskie, Finanse i Marketing, 5(54), 101-114. Retrieved from http://www.wne.sggw.pl/czasopisma/pdf/PEFIM_nr_54 2011_s101.pdf

Modigliani, F. (1961). Long-run implications of alternative fiscal policies and the burden of the national debt. Economic Journal, 71(284), 730-755.

Parkinson, M., Champion, T., Simmie, J., Turok, I., Crookston, M., Katz, B., and Park, A. (2006). State of the English cities. Social research (NatCen). The Office of the Deputy Prime Minister, 2. Retrieved from http://image.guardian.co.uk/sys-files/Politics/documents/2006/03/07/StateoftheEnglishCitiespart1.pdf

Pietrzyk, I. (2000). Konkurencyjność regionów w ujęciu Komisji Europejskiej. In M. Klamut, and L. Cybulski (Eds.), Polityka regionalna i jej rola $w$ podnoszeniu konkurencyjności regionów (pp. 20-30). Wrocław: Wydawnictwo Akademii Ekonomicznej we Wrocławiu.

Ponikowski, H. (2004). O miernikach konkurencyjności regionalnej. Roczniki Nauk Społecznych, 32(3), 241-247.

Porter, M.E. (2003). The economic performance of regions. Regional Studies, 37(6\&7), 549-578.

Reinhart, C., and Rogoff, K. (2010). Growth in a time of debt. American Economic Review, 100(2), 573-578.

Saint-Paul, G. (1992). Fiscal policy in an endogenous growth model. The Quarterly Journal of Economics, 107(4), 1243-1259.

Schclarek, A. A. (2004). Debt and Economic Growth in Developing and Industrial Countries. Working Papers 2005:34, Lund University, Department of Economics.

Siudek, T., and Zawojska, A. (2014). Competitiveness in the economic concepts, theories and empirical research. Acta Oeconomia, 13(1), 91-108. 
Storper, M. (2008). Community and economics. In A. Amin, and J. Roberts (Eds.), Community, economic creativity, and organization (pp. 37-68). New York: Oxford University Press.

Strahl, D. (2004). Wykorzystanie wskaźnika Herfindalha-Hirschmana do oceny konkurencyjności regionów. In A. Rapacz (Ed.), Konkurencyjność regionów i przedsiębiorstw (pp. 11-20). Wrocław: Wydawnictwo Akademii Ekonomicznej we Wrocławiu.

Szafranek, E. (2010). Determinanty konkurencyjności regionów: ujęcie teoretyczne i empiryczne (Studia i Monografie nr 443). Opole: Wydawnictwo Uniwersytetu Opolskiego.

Szlachta, J. (1996). Główne problemy rozwoju regionalnego Polski na pezełomie XX i XXI wieku. In R. Broszkiewicz, B. Gruchman, J. Hausner, A. Kidyba, A. Klasik, T. Kudłacz, T. Markowski, Z. Mikołajewicz, I. Pietrzyk, W. Sartorius, J. Szlachta. J. Szlanta, B. Winiarski, and J. Zaucha, Strategiczne wyzwania dla polityki rozwoju regionalnego Polski (pp. 16-27). Warszawa: Wydawnictwo Friedrich Ebert-Stiftung.

Trecroci, C., and Salotti, S. (2012). Even worse than you thought: The impact of government debt on aggregate investment and productivity. SSRN Electronic Journal, 1-23. Retrieved from https://doi. org/10.2139/ssrn.2033107

Winiarski, B. (1999). Konkurencyjność: kryterium wyboru czy kierunek strategii i cel pośredni polityki regionalnej? In M. Klamut (ed.), Konkurencyjność regionów (pp. 9-19). Wrocław: Wydawnictwo Akademii Ekonomicznej we Wrocławiu.

Zhao, R., Tian, Y., Lei, A., Boadu, and F., Ren, Z. (2019). The effect of local government debt on regional economic growth in China: A nonlinear relationship approach. Sustainability (Switzerland), 11(11), 1-22. Retrieved from https://doi.org/10.3390/su11113065 